\title{
IMPLEMENTATION OF SANCTIONS IN REGIONAL REGULATION NUMBER 2 YEAR 2020, GOWA DISTRICT PERSPECTIVE SADDU ZARI'AH
}

\author{
Abdul Halim Talli \\ Lecturer at the Faculty of Sharia and Law, UIN Alauddin Makassar
}

\begin{abstract}
The Gowa Regency Government enforces Regional Regulation No. 2/2020 concerning Mandatory Masks and Implementation of Health Protocols in Preventing the Spread of Corona Virus Disease 2019 on September 21, 2020. The enactment of this regional regulation has drawn a lot of criticism and protests from the public, especially those who have been caught in the operation of law enforcement. The bylaw is interesting to study further for reasons. First, this regional regulation was born and enforced for people affected by Covid-19 who feel the impact in various aspects of life. Second, the spread of the 2019 corona virus disease is determined by the Central Government as a non-natural national disaster, therefore the regulations governing it are also stipulated by the Central Government. This study is viewed from two aspects, namely: 1) What is the legal position of Perda No. 2 of 2020 Gowa Regency according tao the laws and regulations in Indonesia? and 2) What is the saddu zari'ah perspective on the enforcement of the sanctions in the perda? This study is expected to provide insight regarding the legal position of Perda No. 2 of 2020, Gowa Regency, as well as revealing the saddu zari'ah perspective on the imposition of sanctions in the perda. This discussion uses a juridical-syar'iy approach. This study shows that Regional Regulation Number 2 of 2020 Gowa Regency is legal and binding in accordance with the applicable laws and regulations. The Perda fulfills the formal and material requirements in the formation of legislation in Indonesia. Meanwhile, the saddu zari'ah perspective on the imposition of sanctions in this regional regulation is in accordance with the Shari'a, because the imposition of sanctions leads people to comply with the obligation to wear masks and implement health protocols to avoid and control the transmission of covid-19.
\end{abstract}

\section{Keywords:}

Perda On Masks, Sanctions, Avoiding Covid-19

Abstrak

Pemerintah Kabupaten Gowa memberlakukan Peraturan Daerah No. 2 Tahun 2020 tentang Wajib Masker dan Penerapan Protokol Kesehatan dalam Pencegahan Penyebaran Corona Virus Disease 2019 pada 21 September 2020. Pemberlakuan perda ini menuai banyak kritik dan protes masyarakat, khususnya masyarakat yang terjaring 
dalam operasi yustisi penegakan perda. Perda tersebut menarik dikaji lebih lanjut dengan alasan. Pertama, perda ini lahir dan ditegakkan kepada masyarakat yang terdampak covid-19 yang merasakan dampak dalam berbagai aspek kehidupan. Kedua, penyebaran corona virus disease 2019 ditetapkan oleh Pemerintah Pusat sebagai bencana nasional nonalam, karenanya regulasi yang mengaturnya pun ditetapkan oleh Pemerintah Pusat. Kajian ini dilihat dari dua aspek, yaitu: 1) Bagaimana kedudukan hukum Perda No. 2 Tahun 2020 Kabupaten Gowa menurut peraturan perundangan-undangan di Indonesia? dan 2) Bagaimana perspektif saddu zari'ah terhadap pembelakuan sanksi dalam perda tersebut? Kajian ini diharapkan dapat memberikan pencerahan terkait dengan kedudukan hukum Perda No. 2 Tahun 2020 Kabupaten Gowa, serta mengungkap perspektif saddu zari'ah terhadap pemberlakuan sanksi dalam perda tersebut. Pembahasan ini menggunakan pendekatan yuridis-syar'iy. Kajian ini menunjukkan bahwa Perda Nomor 2 Tahun 2020 Kabupaten Gowa adalah sah dan mengikat sesuai peraturan perundang-undangan yang berlaku. Perda tersebut memenuhi syarat formal dan syarat materiel dalam pembentukan perundangundangan di Indonesia. Sedangkan perspektif saddu zari'ah terhadap pemberlakuan sanksi dalam perda tersebut adalah sesuai dengan syariat, karena pemberlakuan sanksi mengantarkan masyarakat untuk mematuhi kewajiban memakai masker dan pelaksanaan protokol kesehatan guna menghindari dan mengendalikan penularan covid-19 tersebut.

Kata Kunci:

Perda tentang Masker, Sanksi, Hindari Covid-19

\section{A. INTRODUCTION}

$\mathrm{t}$ the end of 2019, a new virus that had infected humans was reported in
Wuhan China. This virus became known as the corona virus disease (Covid-
19). The spread is so fast that the World Health Organization in early 2020 has declared it a global pandemic.

In Indonesia, the development of the spread of covid-19 is very significant. In early February 2020 this virus was found in 2 sufferers. After a year later, the Covid19 Task Force Team Report stated that the infected cases dated February 16, 2021 were 1,233,959, recovered 1,039,674, died 33,596.

The emergence of covid -19 has stressed the inhabitants of the earth. Its spread is fast spreading and its impact is very big for the global community. As a result of the spread of covid-19, the Government of Saudi Arabia closed several months of arrival of prospective Umrah pilgrims from outside, and in 2020 held Hajj and Umrah with a total congregation of approximately 2000 people. Likewise the Indonesian Government, various policies were issued to control the spread of covid19. Starting from Large-Scale Social Restrictions (PSBB), prohibiting homecoming, prohibiting travel to the Community Activity Restriction Program (PPKM).

The Indonesian government policy is seen as still needing to be emphasized. 
Various regulations were issued such as government regulations, presidential instructions, ministerial regulations and ministerial instructions as well as implementation instructions and other technical instructions. However, the results are still considered vulnerable and less effective in controlling the spread of covid-19. The community is still lacking in discipline, it still takes appropriate steps in handling it. Therefore, the central government provides opportunities for local governments to take policy steps in an effort to control the spread of covid-19, including in the form of issuing regional regulations.

Gowa Regency, South Sulawesi Province is one of the districts affected by the second Covid-19 after Makassar City. Gowa Regency and Maros Regency are the two supporting districts for Makassar City - the capital city of South Sulawesi Province. Gowa Regency is the gateway from the south to Makassar. With this strategic position, the mobilization of residents of Gowa Regency to Makassar is very high. The number of Covid-19 sufferers from Gowa Regency dated February 14, 2021 was 4,954 people, with details: 399 people who were treated, recovered 4555 people, and died 60 cases $^{1}$.

The Gowa Regency Government has made various efforts to prevent the transmission of Covid-19 in the Gowa Regency area with policies including: optimizing socialization and dissemination of information about the dangers of the 2019 corona disease virus both through the local government by announcing in mosques, distributing banners and panplets, or through social media whatsapp, fecebook, instagram, etc. Even the Gowa Regency Government has implemented sub-district scale social restrictions in 18 sub-districts in Gowa Regency.

The policy of the Gowa Regency Government in controlling the spread of covid19 still needs stronger support from the community, more compliance with wearing masks and implementation of other health protocols is needed. Therefore, to improve community discipline in Gowa Regency, the Government of Gowa Regency stipulates and enforces Regional Regulation no. 2 of 2020 concerning Mandatory Masks and Implementation of Health Protocols in Preventing the Spread of Corona Virus Disease 2019 on September 14, 2020, promulgated in Sungguminas on September 21, 2020, and published on the Regional Gazette of Gowa Regency 2020 Number 02 with the register number of the Gowa Regency Regional Regulation South Sulawesi Province B.HK.002.08.20.

Enforcement of Regional Regulation No. 2 of 2020 has drawn a lot of criticism and protests from the public, especially those who have been caught in the justisi operation of enforcing local regulations. People who were sanctioned because they were found by officers not wearing masks in public places, did not accept the imposition of these sanctions. Likewise, some people think that this policy is too much. The public is sufficiently reminded and advised to always wear masks and apply health protocols.

The presence of Perda No. 2 of 2020 Gowa Regency is interesting to be studied,

${ }^{1}$ https://satgascovid-19 Sulawesi Selatan. Quoted from Fajar, Wednesday, February 24, 2021, p. 8.

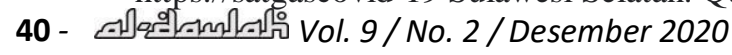


analyzed, and further researched for several reasons. First, this regional regulation was born and enforced for people affected by Covid-19 who feel the impact in various aspects of life. Communities affected by non-natural disasters should receive assistance and services, not the sanctions they have experienced. Second, the spread of the 2019 corona virus disease is determined by the Central Government as a nonnatural national disaster. Therefore, the regulations governing it are set by the Central Government. Thus, local governments should simply follow the regulations set by the central government. There is no need for the Regional Government to make separate regulations in dealing with Covid-19.

This study will be viewed from two aspects, namely: 1) What is the legal standing of Perda No. 2 of 2020 Gowa Regency according to the laws and regulations in Indonesia? and 2) What is the saddu zari'ah perspective on the enforcement of sanctions in Perda No. 2 of 2020 Gowa Regency? This study is expected to provide insight regarding the legal position of Perda No. 2/2020 Gowa Regency, as well as revealing the saddu zari'ah perspective on the imposition of sanctions in the perda. This discussion uses a juridical-syar'iy approach.

There have not been many special studies related to the enactment of the mandatory regional regulation on wearing masks, but studies on the application of wearing masks and health protocols to protect themselves from the spread of Covid19 have been carried out by many experts in the health sector. Research on the application of health protocols and the use of masks in dealing with the spread of Covid-19 has been widely carried out. Of course it is very reasonable, because since the beginning of the spread of Covid-19 until now, propaganda on the use of masks and the application of health protocols is still being carried out, both by the government, information media institutions, socio-religious organizations, and others. Among these studies include: Joko Triatmojo, et al. , stated that the use of masks is the main choice of the world community (universal masking) in preventing the spread of covid-19. With the method of collecting and analyzing articles from various sources that discuss the types of masks that are affective to use, Triatmojo concluded that N59 masks and surgical masks have an effective rate of above $90 \%$ in protecting the wearer from virus penetration through the nose and mouth. Then a 3layer cloth mask with the composition of the inner layer of cotton, the middle layer of woven polypropylene and the outer layer of polyester. This research indicates the need for discipline in using the right mask. Quoting WHO guidelines, that using a mask must pay attention to hand hygiene when wearing and changing, masks must cover the mouth and nose appropriately, avoid touching the inside directly, replace new ones immediately if the mask is damp and contaminated with droplets, and clean the mask with soap and antiseptic. alcoholic before reuse.

Ni Made Nopita Wati, et al. , said that one of the efforts to protect yourself from the spread of the corona virus is the use of personal protective equipment. Personal protective equipment is a device that has the ability to protect a person by isolating part or all of the body from potential dangers. One of them is a mask. Masks are a means of covering the face to protect themselves from spreading the virus through 
the nose and mouth when interacting with other people. Masks can insulate the mouth and nose from the penetration of droplet fluids and transmission of infection through the air. According to Wati, providing public understanding in the form of counseling needs to be continuously encouraged, especially regarding the importance of a clean and healthy lifestyle. With a clean and healthy lifestyle, people will be avoided and can overcome the corona virus.

The massive spread of the corona virus, which has a wide impact on society in various fields of life, requires serious and systematic handling. One of them is increasing the discipline of wearing masks for the community when outside the home. Discipline on wearing masks is very important, because don't let one person not wear a mask instead he is the one who spreads the virus to many people which causes prolonged suffering. Therefore, citizen discipline through the implementation of regional regulations can be appreciated. Discipline enforcement and administrative fines should be developed. According to Sayoga, as quoted by Ida Bagus Brahmana, the imposition of administrative sanctions is not for finding fault and fines the community, but is intended to discipline people to wear masks and health protocols in tackling the spread of covid-19.

This research was conducted with the aim of knowing the legal standing of the Perda Mandatory Wearing a Mask in Gowa Regency according to the applicable laws and regulations, and knowing the saddu zari'ah perspective on the imposition of sanctions on the Mandatory Wear Mask Regulation in Gowa Regency.

\section{B. RESEARCH METHOD}

This research is a research library, which is a library research that raises data related to the application of sanctions on the mandatory regional regulation to wear masks in Gowa Regency. This study describes the implementation of the imposition of sanctions on the mandatory regional regulations to wear masks for people in Gowa Regency with the saddu zari'ah perspective. This study is discussed with the juridical syar'iy approach, which is to use an analysis knife of applicable laws and regulations and methods of determining saddu zari'ah laws. The discussion about the legal position of the mandatory local regulation to wear a mask is discussed using an analysis of the applicable laws and regulations, and saddu zari'ah as a method of determining the law will be used in analyzing legal provisions regarding the imposition of sanctions for violators not wearing masks.

This research focuses on tracing the latest journals, laws and regulations, reports related to the obligation to wear masks and the application of other health protocols. In collecting library data, various instruments are used, such as billboards, note sheets, and cell phones.

Furthermore, the collected data is processed in the form of sorting between related and unrelated data. Classification and separation between main, supporting, and complementary data. After that, the data were analyzed based on the formulation of the problem, synchronization and interpretation were carried out. 


\section{RESEARCH RESULT}

The results show that the preparation and stipulation of Regional Regulation Number 2 of 2020 in Gowa Regency is a realization of the instruction of the minister of home affairs as a technical guideline for drafting local regulations, both regarding the format, structure, and content elements. This ministerial instruction is an implementation of the previous presidential instruction. This shows that the presence of the Gowa Regency Regional Regulation Number 2 of 2020 is the realization of a presidential instruction that was passed on by the minister of the interior. Thus, the legal position of this regional regulation is valid in accordance with statutory regulations.

In the perspective of saddu zari'ah, the efforts of the Regional Government of Gowa Regency to impose a regional regulation that is obliged to wear masks for people in public places, such as on the streets, markets, mosques and crowded places is in accordance with Islamic law.

\section{DISCUSSION}

\section{The basis for drafting local regulations no. 2 of 2020 Gowa Regency}

a. UU no. 24 of 2007 concerning Disaster Management

Law Number 24 of 2007 concerning Disaster Management stipulates that the government is obliged and responsible for carrying out disaster management efforts. Article 5 states that "The government and local governments are responsible for implementing disaster management." This provision shows that the responsibility for handling a disaster rests with the government and local governments. The government is obliged to take policies and steps in dealing with disasters that occur and strive to minimize casualties due to disasters. The government must as soon as possible make efforts to protect the community due to disasters and reduce the risk of disasters that occur.

The provisions of articles 6 and 7 regulate the responsibilities and authorities of the central government. The central government, as the national responsibility for disaster management, has the obligation to undertake response measures in the form of: disaster risk reduction, protection of the community from the impact of disasters, fulfillment of community and refugee rights, minimizing impacts, preparing disaster management budget and its consequences, and maintaining threat files and the impact of the disaster. In fulfilling these obligations, the central government has the authority in terms of: determining disaster management policies, making management plans, determining disaster status, determining cooperation policies, formulating the use of technology, formulating policies to prevent the depletion of natural resources, and controlling the collection of funds and goods of a national nature ${ }^{2}$. Furthermore, local governments have responsibility at the regional / local level in dealing with disasters in their region. Some of the obligations of the regional

\footnotetext{
${ }^{2}$ See in full Article 6-7 Undang-undang Nomor 24 Tahun 2007 tentang Penanggulangan Bencana.
} 
government are: guaranteeing the fulfillment of the rights of the community and refugees according to minimum service standards, protecting the community from disasters, reducing disaster risks, and allocating adequate disaster management budgets in the APBD. In fulfilling these obligations, regional governments have the authority to: stipulate disaster management policies in their territories, formulate disaster management development plans, implement collaborative policies, regulate the use of potentially hazardous technology, formulate policies on control and drainage of natural resources, and regulate the collection of money and goods in its territory ${ }^{3}$.

The existence of a stipulation that the central government and regional governments are responsible for disaster management, both national and local / regional disasters is certainly very reasonable. Remember because Indonesia always experiences disasters. Indonesia's vast territory with geographic, demographic, geological, and hydrological conditions has the potential for disasters to occur at any time. In a period of one month in early 2021, Indonesia was plagued by continuous disasters, ranging from flash floods, landslides, the rapid fall of Sriwijaya Air, earthquakes, fires, volcanic eruptions, and other disasters. BNPB notes that it in the range of 1 s.d. January 23, there were 197 cases of disasters spread across Indonesia ${ }^{4}$.

According to Law Number 24 of 2007 concerning Disaster Management, Article 1 point (1) describes the definition of disaster, as reiterated in Government Regulation Number 21 of 2008 in Article 1 number (1), that "Disaster is an event or series of events that threatens and disrupts life. and people's livelihoods which are caused by, both natural and / or non-natural factors as well as human factors, resulting in casualties, environmental damage, property loss and psychological impacts ". This definition indicates that a disaster consists of three elements, namely: 1) the occurrence of an event or series of events that threatens and disrupts people's lives and livelihoods; 2) natural or non-natural factors, as well as human factors; and 3) causing casualties and / or environmental damage / property loss / psychological impact $^{5}$.

The government, as mandated by the 1945 Constitution of the Republic of Indonesia, is obliged to protect the entire nation and all Indonesian bloodshed. The government in carrying out development must strive for the realization of a just people's welfare, fulfilling the right to life and livelihoods of the community, as well as protection for every citizen ${ }^{6}$, including protection from disasters and overcoming them. The General Elucidation of Law Number 24 of 2007 states that the potential causes of disasters in Indonesia are grouped into three types of disasters, namely

\footnotetext{
${ }^{3}$ See in full Article 8-9 Undang-undang Nomor 24 Tahun 2007 tentang Penanggulangan Bencana.

${ }^{4}$ https://www.minded-rakyat.com/nasional/pr-011320247/duka-awal-tahun-2021-197-bencana-alamterjadi-di-indonesia-dalam-waktu-kurang-dari-satu-bulan.

${ }^{5}$ R. Julio Prasetyo, Pengadaan Barang/Jasa Pemerintah dalam Penyelenggaraan Penanggulangan Bencana, Journal of Jurist-Diction, Vol. 2, No. May 3, 2019, p. 1104.

${ }^{6}$ Jimly Asshiddiqie, Pokok-pokok Hukum Tata Negara Indonesia Pasca Reformasi, (Cet. II; Jakarta: PT Bhuana Ilmu Populer, 2008) p. 446.

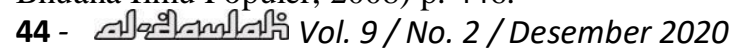


natural disasters, non-natural disasters and social disasters ${ }^{7}$. All these potential disasters require professional, prompt, accountable and responsible handling.

b. UU no. 23 of 2014 concerning Regional Government

As a unitary state of the Republic of Indonesia, the administration of the state government is under the power of the President. The President as the head of government is responsible for carrying out government affairs which are organized based on the principles of decentralization, deconcentration and assistance tasks ${ }^{8}$. In carrying out government affairs, the central government designs and determines policies as the basis for administering government affairs. The administration of government affairs, both central and regional governments, is under the final responsibility of the president ${ }^{9}$.

The Unitary State of the Republic of Indonesia consists of provincial areas consisting of regencies and cities ${ }^{10}$. Provinces are led by governors, regencies are led by regents, and cities are led by mayors. The provincial area becomes an administrative area which becomes the working area for the governor as the representative of the central government and as the governor's working area in administering general government in the province. The regency / city is an administrative area which is also the working area of the regent / mayor in administering general governance in the regency/city area ${ }^{11}$.

Governmental affairs in the Republic of Indonesia consist of absolute government affairs, concurrent government affairs, and general government affairs. Absolute governmental affairs are governmental affairs fully under the authority of the central government, covering the fields of foreign policy, defense, security, justice, national monetary and fiscal, and religion. Concurrent government affairs are government affairs that are divided between the central government and provincial and district / city governments. These governmental affairs are left to the regions as the basis for implementing regional autonomy, which consists of mandatory government affairs and optional government affairs. Government affairs must consist of government affairs related to basic services and those not related to basic services. Compulsory government affairs related to basic services are compulsory government affairs of which some of the substance are basic services, namely in the fields of: education, health, public works and spatial planning, public housing and residential areas, peace, public order, and protection of the community and society. Meanwhile, mandatory government affairs that are not related to basic services include the following fields: manpower; empowerment of women and child protection; food; land; environment; population administration and civil registration; community and village empowerment; population control and family planning; transportation; communication and informatics; cooperatives, small and medium

\footnotetext{
${ }^{7}$ See General Elucidation of UU Nomo 24 Tahun 2007 tentang Penanggulangan Bencana.

${ }^{8}$ Article 5 paragraph (4) of UU Nomor 23 Tahun 2014 tentang Pemerintahan Daerah.

${ }^{9}$ Article 7 paragraph (2) of UU Nomor 23 Tahun 2014 tentang Pemerintahan Daerah.

${ }^{10}$ Article 2 of UU Nomor 23 Tahun 2014 tentang Pemerintahan Daerah.

${ }^{11}$ Article 4 of UU Nomor 23 Tahun 2014 tentang Pemerintahan Daerah.
} 
enterprises; capital investment; youth and sports; statistics; coding; culture; library; and archiving. The selected governmental affairs include the following fields: maritime affairs and fisheries; tourism; agriculture; forestry; energy and Mineral Resources; trading; industry; and transmigration ${ }^{12}$.

The provisions above indicate that the Regency / City Government as the administrator of general government in the regency / city area is obliged to carry out mandatory government affairs that are directly related to basic services.

c. Presidential Instruction No.6 of 2020

The Government of Gowa Regency has stipulated and enforced Regional Regulation Number 2 of 2020 concerning Mandatory Masks and Implementation of Health Protocols in the Prevention of the Spread of Corona Virus Disease 2019. This regional regulation was enacted on September 14, 2020 and declared in effect from the date of its enactment.

Regional Regulation Number 2 of 2020 Gowa Regency is a follow-up to Presidential Instruction Number 6 of 2020 concerning Increasing Discipline and Law Enforcement of Health Protocols in the Prevention and Control of Corona Virus Disease 2019 which was issued on August 4, 2020. Through this presidential decree, President Joko Widodo instructed Cabinet Ministers, TNI Commander, Chief of Police, Heads of Non-Ministry Government Institutions, Governors, and Regents / Mayors to take the necessary steps according to their duties and functions in ensuring legal certainty, and strengthening efforts to prevent and control Covid-19 throughout the Republic of Indonesia ${ }^{13}$.

Especially for governors, regents / mayors were instructed to carry out 4 things in order to strengthen efforts to control the spread of covid-19, namely: 1) to conduct massive outreach on the importance of following health protocols by involving the community, religious leaders, traditional leaders, and other elements of society. ; 2) formulating and stipulating regional regulations that require implementing health protocols for individuals, business actors and managers of public facilities, and protecting public health; 3) drafting local regulations on the obligation to comply with health protocols in controlling the spread of covid-19 while still paying attention to the local wisdom of each area; and 4) in enforcing sanctions for violators of regional regulations, involving the relevant ministries / agencies, elements of the TNI and Polri.

Based on Inpres No. 6 of 2020, then on August 10, 2020, the Minister of Home Affairs issued Instruction Number 4 of 2020 concerning Technical Guidelines for the Formulation of Regional Head Regulations in the Context of Discipline Implementation and Law Enforcement of Health Protocols as Efforts to Prevent and Control Corona Virus Disease 2019 in the Regions. This instruction is addressed directly to the Governors and Regents / Mayors of Suluruh Indonesia to take steps in terms of: 1) conducting massive outreach on the implementation of health protocols

\footnotetext{
12 Article 9-12 of UU Nomor 23 Tahun 2014 tentang Pemerintahan Daerah.

${ }^{13}$ Instruksi Presiden Republik Indonesia Nomor 6 Tahun 2020 tentang Peningkatan Disiplin dan Penegakan Hukum Protokol Kesehatan dalam Pencegahan dan Pengendalian Corona Virus Disease 2019.

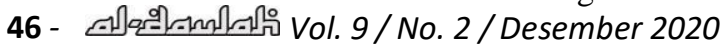


in the prevention and control of covid-19; 2) compile and stipulate regional regulations regarding the implementation of health protocols in an effort to prevent and control the spread of corona virus disease 2019 according to the format listed in the attachment to this instruction; 3) drafting of the said regional regulations with due observance of regional local wisdom ${ }^{14}$. This instruction also instructs the governor and regent / mayor to formulate these regional regulations responsibly within a span of 14 days, and to immediately report the implementation of this instruction to the Minister of Home Affairs.

\section{Analysis of the Establishment of Perda No. 2 of 2020 Gowa Regency}

The formulation and enactment of Regional Regulation Number 2 of 2020 Gowa Regency concerning Mandatory Masks and Implementation of Health Protocols in Preventing the Spread of Corona Virus Disease 2019 is one of the efforts of the Gowa Regency Government in handling and controlling the spread of covid-19 in the Gowa Regency area. The stipulation and enforcement of these regional regulations have legal standing according to statutory regulations.

The legal position of a regulation in the territory of the Republic of Indonesia, including Perda No. 2/2020 of Gowa Regency must be based on the applicable laws and regulations. According to Michael A. Pangemanan, as quoted by Asri Lasto, he stated that in the preparation of statutory regulations, it refers to four regulations, namely: 1) Law Number 12 of 2011 concerning the Formation of Laws and Regulations, as amended by Law Number 15 of the Year 2019 concerning Amendments to Law no. 12 of 2011 concerning the Establishment of Legislation; 2) Law Number 23 of 2014 concerning Regional Government which has been amended by Law Number 15 of 2019 concerning Amendments to Law Number 23 of 2014 concerning Regional Government; 3) Presidential Regulation Number 87 of 2014 concerning Implementation Regulations of Law Number 12 of 2011 concerning the Formation of Legislation; 4) Regulation of the Minister of Home Affairs Number 80 of 2015 concerning the Formation of Regional Legal Products as amended by the Regulation of the Minister of Home Affairs Number 120 of 2018 concerning Amendments to the Regulation of the Minister of Home Affairs Number 80 of 2015 concerning the Formation of Regional Legal Products. The four laws and regulations contain formal requirements and material requirements that must be met. The formal requirements include procedural and administrative requirements ${ }^{15}$, while the material requirements regarding the content or substance contained therein ${ }^{16}$. The material content of regional regulations includes the implementation of regional autonomy and the implementation of assistance tasks, as well as in the context of

\footnotetext{
${ }^{14}$ See further Instruksi Menteri Dalam Negeri Nomor 4 Tahun 2020 tentang Pedoman Teknis Penyusunan Peraturan Kepala Daerah dalam Rangka Penerapan Protokol Kesehatan sebagai Upaya Pencegahan dan Pengendalian corona Virus Disease 2019 di Daerah.

${ }^{15}$ See Muhammad Suharjono, Pembentukan Peraturan Daerah yang Responsif Mendukung Otonomi Daerah, Jurnal Ilmu Hukum, Vol. 10, No. 19, Pebruari 2014, p. 32.

${ }^{16}$ Ari Lasatu, Urgensi Peraturan Daerah tentang Program Pembentukan Peraturan Daerah Terhadap Kinerja DPRD “Jurnal Ilmiah Kebijakan Umum” Vol. 14 No. 2 Tahun 2020, p. 203. 
implementing higher legislation ${ }^{17}$. In addition, in accordance with the provisions of Article 236 paragraph (3) and (4) of Law Number 23 of 2014, regional regulations can also be about local content, or the character and special potential of regions intended for improving the welfare of the community ${ }^{18}$.

The formal requirements for the formation of regional regulations include the filing procedure, the stages that must be passed in the preparation, as well as other requirements stipulated by statutory regulations ${ }^{19}$.

Regional Regulation Number 2 of 2020 Gowa Regency has met the formal and material requirements, and its preparation is carried out according to the procedure and through the stages stipulated in the legislation.

\section{Conception of Saddu Zaria'ah}

The word saddu zari'ah comes from Arabic. Saddu means to close, clog up ${ }^{20}$. Zari'ah means introduction, intermediary, mediator ${ }^{21}$. Saddu al-zari'ah means to close or block the intermediate pathway for something to happen. The word al-zara'i is the plural form of al-zari'ah which means anything that acts as an intermediary / way to something else. In terminology, it is defined as any intermediary (action or word or other) whose basic law may be intended for mafsadat purposes, or not intended for mafsadat purposes, but in general mafsadat that is manifested, mafsadat is stronger than maslahat. In other words, saddu zari'ah is stopping matter or something that is the medium of mafsadat by closing and rejecting the intermediary ${ }^{22}$. Imam AsySyatibi defines saddu al-zari'ah as closing the road or stopping a job / activity that was previously permitted because it will lead to a destitution. That is, prohibiting someone from doing something that is basically permissible because it contains benefit, but the goal that will be achieved is immunity. Ibn Qayyim al-Jauziyah added that the meaning of al-zari'ah is not only about something that is prohibited, but also on something that is recommended. According to him, just interpreting alzari'ah to something that is prohibited is not correct ${ }^{23}$.

The explanation above shows that saddu zari'ah is one of the methods of taking the law by focusing on the aspect of an intermediary or something that leads to the occurrence of $\mathrm{fade}^{24}$. The definition of al-zari'ah includes two things, namely

${ }^{17}$ See Muhammad Asrianto Zainal, Proses Pembentukan Peraturan Daerah Kabupaten Muna Sulawesi Tenggara, Al Izzah: Jurnal Hasil-hasil Penelitian, Vol. 13, No. 2, November 2018, p. 213.

${ }^{18}$ See Dalinama Telaumpanua, Pembentukan Perturan Daerah Kabupaten/Kota, Jurnal Education and Development Institut Pendidikan Tapanuli Selatan, Vol. 4 No. 1 Edisi April 2018, p. 98.

${ }^{19}$ Absori, Fatkhul Muin, Penyusunan Peraturan Daerah dalam Kerangka Otonomi Daerah: Suatu Tinjauan Terhadap Pembentukan Perda yang Aspiratif, Prosiding Konferensi Nasional Ke-4 Asosiasi Program Pascasarja Perguruan Tinggi Muhammadiyah (APPPTM), ISBN: 978-602-19568-1-6, p. 269.

${ }^{20}$ Louis Ma'luf, Al-Munjid fi al-Lughah wa al-I'lam (Bairut: Dar al-Masyriq, 1986) p. 326.

${ }^{21}$ Louis Ma'luf, Al-Munjid fi al-Lughah wa al-I'lam, p. 479.

${ }^{22}$ See Abdul Karim ibn 'Ali ibn Muhammad al-Nimlah, al-Muhazzab fi Ilm Ushul al-Fiqh al-Muqaran, Jilid 3 (Cet. 3; Riyad: Maktabah al-Rusd, 1424/2004) p. 1016.

${ }^{23}$ See Abdul Azis Dahlan (editor), Ensiklopedi Hukum Islam, Jilid 6, (Cet. 1; Jakarta: Ichtiar Baru Van Hoeve, 1996) p. 2005.

${ }^{24}$ Nurdhin Baroroh, Metamorfosis "Illat Hukum" dalam Sad adz-Dzariah dan Fath adz-Dzariah (Sebuah Kajian Perbandingan), Jurnal al-Mazahib, Volume 5, Nomor 2, Desember 2017, p. 294.

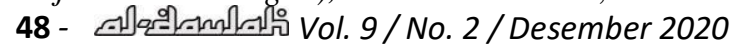


prohibiting an intermediary because it will cause harm, and or ordering an intermediary to avoid mafsadat ${ }^{25}$.

Saddu zari'ah as a method of legal determination has been used by jumhur ulama $^{26}$. They base their views on the Qur'an, Hadith, and Ijmak. Referring to the AlQur'an, jumhur raised the following QS al-An'am / 6 verse 108:

$$
\text { ولا تسبوا الذين يدعون من دون الله فيسبوا الله عدوا بغير علم كذلك زينا لكل أمة عملهم ثم إلى ربهم مرجعهم فينبئهم بما }
$$

-108- كانوا يعملون -

This verse contains a prohibition against insulting the worship of an unbeliever, because a disbeliever will later insult Allah, even the insults go beyond the limit without any basis of knowledge. Allah SWT forbids His servants from berating Allah, Rasul, angels and other creatures. Muslims are prohibited from swearing, blaspheming and denouncing Allah's creation (QS al-Hujurat / 49: 11). Because this attitude is contrary to the behavior of being grateful for the blessings of Allah (QS alBaqarah / 2: 152) ${ }^{27}$. On the contrary, to purify and purify Allah from anything that is not worthy of Him is Allah's command. Likewise, glorifying and glorifying Allah are praiseworthy attitudes and behaviors ${ }^{28}$.

Scolding the idolatrous worship which is meant to purify Allah from anything that is not worthy of Him is something good (maslahat). However, because insulting the worship of an unbeliever will make an unbeliever insult Allah, even his insults are more than the insults of the believers so that the act of insulting the idol's worship is not permitted. This prohibition against insulting the worship of an infidel like this is what is meant by saddu zari'ah ${ }^{29}$.

The second foundation is hadith as practiced by the Prophet. The friend hinted at the Messenger of Allah to destroy the hypocrites who were blatantly showing their hypocrisy. But Rasulullah responded by saying: "I am afraid that people will say that Muhammad destroyed his companions." The Prophet disliked eliminating hypocrites by preaching on them. Reluctance to destroy these hypocrites because it was feared that it would cause slander that the Prophet Muhammad had destroyed his companions, that is saddu zari'ah. Meanwhile, the foundation of ijmak regarding the saddu zari'ah hujjahan has been practiced by Khulafaurrasyidin. Umar bin Khattab forbade prayer under the Bai'at Ridwan tree, then Umar cut down the tree. This is intended to prevent people from reverting to shirk like the era of the ignorance ${ }^{30}$.

${ }^{25}$ Wahbah al-Zuhaily, Ushul al-Fiqh al-Islamy, Juz II (Bairut: Dar al-Fikr al-Mu'asir, 1986), p. 173.

${ }^{26}$ Hifdhotul Munawarah, Sadd al-Dzari'at dan Aplikasinya pada Permasalahan Fiqih Kontemporer, Jurnal Ijtihad, Vol. 12, No. 1, Juni 2018, p. 82.

${ }^{27}$ Muhammad Takhim, Saddu al-Dzariah dala Muamalah Islam, Akses: Jurnal Ekonomi dan Bisnis, Vol. 14, No. 12019 , p. 20.

${ }^{28}$ M. Quraish Shihab, Tafsir Al-Mishbah: Pesan, Kesan dan Keserasian Al-Qur'an, Volume 4 (Cet. V; Jakarta: Lentera Hati, 2006, p. 243.

${ }^{29}$ Yusep Rafiqi, dkk., Implementasi Sadd dan Fath al-Dzari'ah dalam Strategi Pemasaran Produk Bordir di Sentra Industri Bordir Kota Tasikmalaya, Al Mashlahah: Jurnal huku Islamm dan Pranata Sosial, Vol. 07, No. 2 Oktober 2019, p. 152.

${ }^{30}$ Abdul Karim ibn 'Ali ibn Muhammad al-Nimlah, al-Muahazzab fi Ilm Ushul al-Fiqh al-Muqaran, Jilid 3, p. 1017. 
Ibn Qayyim al-Jauziyah divided saddu zari'ah into two forms based on the result of an action performed. 1) That act brings a sin, such as drinking khamar will cause drunkenness, and drunkenness is evil. 2) Actions that are basically permissible or recommended, but are used as a way to commit an illegal act, whether with a deliberate or unintentional purpose. For example, an act of haram with a deliberate purpose is a person who marries a woman who has been bullied by her husband by three with the aim that the woman's first husband can remarry her. Meanwhile, an example of an act that was committed unintentionally from the beginning is insulting another person's parents, as a result of this cacimaki his parents were also scolded by the other person. The two deeds are divided into the benefit of which is stronger than that of the kemāaslahatan, and the deeds whose fade is stronger than that of his wickedness. The two divisions have four forms, namely: 1) Intentionally aimed at a compactness; 2) Actions which are basically permissible but aimed at an immolation; 3) The act which is basically permissible and the perpetrator does not intend to be inconsistent, but is strongly suspected to cause incompetence; 4) An act that is permissible but sometimes it can lead to infidelity ${ }^{31}$.

\section{Saddu Zari'ah's perspective on the Application of Sanctions in Perda No. 2/2020 Gowa Regency}

The sanctions provisions in Perda No. 2/2020 Gowa Regency are regulated in Chapter XII Article 31 concerning Administrative Sanctions. This article states that the regent has the authority to impose administrative sanctions on every business actor, head of regional apparatus / agency / private institution, village head and village apparatus who violate this regional regulation. Administrative sanctions consist of: verbal warning, written warning, temporary closure of business premises, revocation of business licenses and / or business permits. In addition, fines for violating health protocols are Rp. 200,000 for business actors, Rp. 150,000 for civil servants, village heads and village officials, and Rp. 100,000 or social sanctions for the community. In implementing sanctions, the regent may delegate this authority to regional apparatuses / agencies in accordance with their duties and functions.

The enactment of this Perda is intended as a basis for implementation in efforts to prevent and manage the risk of covid-19 transmission in the Gowa Regency area, as well as a legal basis for law enforcers in maximizing the obligation to use masks and implementing health protocols. This regional regulation aims to prevent and reduce the risk of covid-19 transmission, optimize efforts to prevent and treat health due to covid-19, and provide effective protection for everyone from the dangers of covid-19.

The imposition of sanctions in Perda No. 2/2020 of Gowa Regency with the above aims and objectives is in accordance with Islamic law, on the grounds that the imposition of sanctions is intended to optimize compliance with the obligation to

${ }^{31}$ See Abdul Azis Dahlan (editor), Ensiklopedi Hukum Islam, Jilid 6, p. 2007.

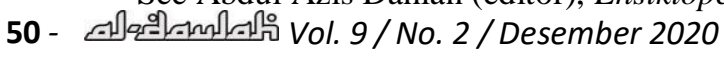


wear masks and the application of health protocols in order to prevent transmission of Covid-1932.

Prevention of covid-19 transmission which is intended to safeguard and maintain public health is an obligation of ulil amri / government. The government is obliged to make efforts to protect the public from being infected or to minimize the occurrence of covid-19 transmission. In making efforts and steps to protect the public from Covid-19, the government can issue orders to do something, and it can also be in the form of a ban on doing something.

In the perspective of saddu zari'ah, the efforts of the Regional Government of Gowa Regency to impose a regional regulation that is obliged to wear masks for people in public places, such as on the streets, markets, mosques and crowded places is in accordance with Islamic law Its suitability is based on the following arguments:

1) The obligation to protect oneself from fade / danger. The obligation to protect oneself from various kinds of fade, including the threat of disease, is a command from Allah that must be carried out. As in Surah al-Baqarah/2: 195,

And infakkanlah (your wealth) in the way of Allah, and do not drop it (themselves) into destruction with your own hands, and do good, truly Allah loves those who do good ". Protecting oneself from disease is a virtue that is commanded by Allah. It is obligatory for every person (mukallaf) to protect him from various threats, including from the threat of dangerous viruses. The use of masks in normal conditions is a permissible matter. However, because wearing a mask is one of the effective ways to protect yourself from covid-19 transmission, the use of a mask is a must so that the wearer is protected from covid-19 transmission. Here, wearing a mask becomes a "wasilah / intermediary / mediator" to protect yourself from contracting the corona virus. So, wearing a mask is mandatory / mandatory for everyone to avoid the corona virus which will cause illness. This is also in line with the fikhiyah rule which states "Anything without which causes imperfection of an obligation, then something becomes mandatory". So, the use of masks is a complement to fulfilling efforts to protect themselves from transmission of the corona virus through the nasal and oral cavities.

2) Prohibition of spreading and accepting fade. In the law of fiqhiyah

"لاضَرَ وَلاضِِرَار" does not spread kemudaratan and also does not accept kemudaratan. That a person who has deterioration in himself, such as infectious diseases, viruses and others, is not allowed to spread that deterioration to others. Likewise, someone who knows or deserves to be suspected of a virus in a place, is not allowed to come to that place because he is worried that the virus will be affected.

Given that human activities cannot be completely stopped, because they need to earn a living and fulfill other basic needs, the way to protect yourself and others from

${ }^{32}$ See Mushidah, Ratna Muliawati, Pengetahuan dan Sikap dengan Kepatuhan Penggunaan Masker sebagai Upaya Pencegahan Penyebaran Vovid-19 pada Pedagang UMKM, Jurnal Ilmiah Permas, Vol. 11, No. 1 Januari 2021, p. 36 
the spread of the corona virus is to wear a mask. Therefore, to protect yourself and avoid spreading the virus by cursing a mask is a very appropriate effort.

\section{E. CONCLUSION}

The formulation and enactment of Regional Regulation Number 2 of 2020 Gowa Regency concerning Mandatory Masks and Implementation of Health Protocols in Preventing the Spread of Corona Virus Disease 2019 has legal standing according to statutory regulations. This regional regulation has met the formal and material requirements, and its preparation is carried out according to the procedure and through the stages stipulated in the statutory regulations.

As for the imposition of sanctions in Perda No.2 of 2020, Gowa Regency is in accordance with Islamic law, on the grounds that the imposition of sanctions is intended to optimize compliance with the obligation to wear masks and the application of health protocols in order to prevent transmission of Covid-19. The Regional Government of Gowa Regency enforces the mandatory local regulation to wear masks for people in public places, such as on roads, markets, mosques, and crowded places, according to Islamic law. Its suitability is based on several arguments that Allah SWT obliges humans to protect themselves from harm / danger, and the prohibition of spreading and accepting known fade. Allah knows best

\section{References}

Absori, Fatkhul Muin. Penyusunan Peraturan Daerah dalam Kerangka Otonomi Daerah: Suatu Tinjauan Terhadap Pembentukan Perda yang Aspiratif, Prosiding Konferensi Nasional Ke-4 Asosiasi Program Pascasarja Perguruan Tinggi Muhammadiyah (APPPTM), ISBN: 978-602-19568-1-6.

Asshiddiqie, Jimly. Pokok-pokok Hukum Tata Negara Indonesia Pasca Reformasi, (Cet. II; Jakarta: PT Bhuana Ilmu Populer, 2008)

Baroroh, Nurdhin. Metamorfosis "Illat Hukum" dalam Sad adz-Dzariah dan Fath adzDzariah (Sebuah Kajian Perbandingan), Jurnal al-Mazahib, Volume 5, Nomor 2, Desember 2017.

Dahlan, Abdul Azis (editor). Ensiklopedi Hukum Islam, Jilid 6, (Cet. 1; Jakarta: Ichtiar Baru Van Hoeve, 1996) h. 2005

Departemen Agama RI, Al-Qur'an dan Tafsirnya (Edisi yang Disempurnakan), (Cet. III; Jakarta: Departemen Agama RI, 2009)

https://satgascovid-19 Sulsel. Dikutip melalui Fajar, Rabu 24 Februari 2021.

https://satgascovid-19 Sulsel. Quoted via Fajar, Wednesday, February 24, 2021.

https://www.pikiran-rakyat.com/nasional/pr-011320247/duka-awal-tahun-2021-197-

bencana-alam-terjadi-di-indonesia-dalam-waktu-kurang-dari-satu-bulan 
https://www.pikiran-rakyat.com/nasional/pr-011320247/duka-awal-tahun-2021-197bencana-alam-terjadi-di-indonesia-dalam-waktu-kurang-dari-satu-bulan

Instruksi Menteri Dalam Negeri Nomor 4 Tahun 2020 tentang Pedoman Teknis Penyusunan Peraturan Kepala Daerah dalam Rangka Penerapan Protokol Kesehatan sebagai Upaya Pencegahan dan Pengendalian corona Virus Disease 2019 di Daerah.

Instruksi Presiden Republik Indonesia Nomor 6 Tahun 2020 tentang Peningkatan Disiplin dan Penegakan Hukum Protokol Kesehatan dalam Pencegahan dan Pengendalian Corona Virus Disease 2019.

Lasatu, Ari. Urgensi Peraturan Daerah tentang Program Pembentukan Peraturan Daerah Terhadap Kinerja DPRD, Jurnal Ilmiah Kebijakan Umum, Vol. 14 No. 2 Tahun 2020.

Ma'luf, Louis. Al-Munjid fi al-Lughah wa al-I'lam (Bairut: Dar al-Masyriq, 1986).

Munawarah, Hifdhotul. Sadd al-Dzari'at dan Aplikasinya pada Permasalahan Fiqih Kontemporer, Jurnal Ijtihad, Vol. 12, No. 1, Juni 2018.

Mushidah, Ratna Muliawati. Pengetahuan dan Sikap dengan Kepatuhan Penggunaan Masker sebagai Upaya Pencegahan Penyebaran Vovid-19 pada Pedagang UMKM, Jurnal Ilmiah Permas, Vol. 11, No. 1 Januari 2021

Al-Nimlah, Abdul Karim ibn 'Ali ibn Muhammad. al-Muahazzab fi Ilm Ushul al-Figh alMuqaran, Jilid 3 (Cet. 3; Riyad: Maktabah al-Rusd, 1424/2004)

Prasetyo, R. Julio. Pengadaan Barang/Jasa Pemerintah dalam Penyelenggaraan Penanggulangan Bencana, Jurnal Jurist-Diction, Vol. 2, No. 3 Mei 2019.

Rafiqi, Yusep. dkk. Implementasi Sadd dan Fath al-Dzari'ah dalam Strategi Pemasaran Produk Bordir di Sentra Industri Bordir Kota Tasikmalaya, Al Mashlahah: Jurnal huku Islamm dan Pranata Sosial, Vol. 07, No. 2 Oktober 2019

Shihab, M. Quraish. Tafsir Al-Mishbah: Pesan, Kesan dan Keserasian Al-Qur'an, Volume 4 (Cet. V; Jakarta: Lentera Hati, 2006, h. 243

Telaumpanua, Dalinama. Pembentukan Perturan Daerah Kabupaten/Kota, Jurnal Education and Development Institut Pendidikan Tapanuli Selatan, Vol. 4 No. 1 Edisi April 2018.

UU Nomor 23 Tahun 2014 tentang Pemerintahan Daerah.

UU Nomor 23 Tahun 2014 tentang Pemerintahan Daerah.

UU Nomor 24 Tahun 2007 tentang Penanggulangan Bencana.

UU Nomor 24 Tahun 2007 tentang Penanggulangan Bencana.

Zainal, Muhammad Asrianto. Proses Pembentukan Peraturan Daerah Kabupaten Muna Sulawesi Tenggara, Al Izzah: Jurnal Hasil-hasil Penelitian, Vol. 13, No. 2, November 2018.

Zuhaily, Wahbah. Ushul al-Figh al-Islamy, Juz II (Bairut: Dar al-Fikr al-Mu'asir, 1986) 